УДК 477 (336.1)

https://doi.org/10.32689/2708-7530-2020-2(2)-65-87

Федоренко Владислав Леонідович доктор юридичних наук, професор, директор Науково-дослідного центру судової експертизи 3 питань інтелектуальної власності Міністерства юстиції України, Заслужений юрист України, бульвар Л. Українки, 26, офіс 501, м. Київ, 01133; fedorenko900@gmail.com; +38 044 5921401, https://orcid.org/0000-0001-59021226

Федоренко Тетяна Анатоліївна аспірант кафедри соціальної i гуманітарної політики, Національна академія державного управління при Президентові України; лікар вищої категорії Стоматологічного медичного центру Національного медичного університету ім. О.О. Богомольця, 03057, м. Київ, вул. Ежена Потьє, 20, тел: (044) 481-21-55; e-mail: tf-doctor@ukr.net, https://orcid.org/0000-0003-1175-6404

\title{
ГЕНЕЗИС ПРАВОВОГО РЕГУЛЮВАННЯ МІСЦЕВИХ БЮДЖЕТІВ В УКРАЇНІ: ВІД ВАРЯГІВ - ДО СУЧАСНОЇ РЕФОРМИ МІСЦЕВОГО САМОВРЯДУВАННЯ НА ЗАСАДАХ ФІНАНСОВОЇ ДЕЦЕНТРАЛІЗАЦЇ̈
}

Анотація. У публікації досліджуються проблеми витоків місцевих фінансів і місцевих бюджетів в Україні 3 часів утвердження Київського Князівства в IX-X ст. - до триваючої на сьогодні в Україні реформи місцевого самоврядування на засадах фінансової децентралізації.

Здійснено періодизацію генезису місцевих фінансів і бюджетів на Українських землях та виокремлено й охарактеризовано сім наступних періодів: 1 період (VIII-XIII ст.) - формування ранньофеодальної фінансової системи Київського Князівства (Русі) на базі варязької ленної системи та різних зборів і данини, які після хрещення Русі почали збирати не лише князі та бояри, а й метрополити; 2 nеріод (XIII-XVI ст.) - запровадження в Київському, Галицько-Волинському та інших слов'янських князівствах татаро-ординської системи фінансів, заснованої на збиранні «десятини» від всього майна i прибутків «мужів» (глав «дворів»), спочатку ханськими баскаками, а надалі великими князями і метрополитами, які використовували частину зібраного для забезпечення власних місцевих бюджетів; запровадження в українських землях бюджетної системи Великого Князівства Литовського, а пізніше Польського Королівства та Речі Посполитої, які ігнорували потреби розвитку місцевого 
самоврядування в Україні; 3 період (XVI-XVIII ст.) - козацького-гетьманська модель місцевих бюджету, за якої 3 населення продовжувала збиратися десятина і інші збори та мита, а бюджетом Війська Запорізького одноособово (іноді, разом із старшиною) розпоряджався гетьман; запровадження, 3 метою розділення публічних фінансів («скарбу») і гетьманської казни, посади підскарбія («міністра фінансів, зборів і податків») у Конституції П. Орлика 1710 р.; 4 період (XVIII - поч. XX ст.) - руйнування Катериною II Запорізької Січі та козацько-гетьманської фінансової системи і поширення на Українські землі фінансово-бюджетних систем Російської, Австро-Угорської та Отаманської (Південь України) імперій та Румунії (Буковина), які забезпечували фінансування регіонів за остатковим принципом; 5 період (19171922 рр.) - незавершене формування системи місцевих бюджетів за доби національної революції (УНР, ЗУНР, Гетьманат, Директорія); 6 період (1922 1991 рр.) - включення України до складу колишнього СРСР та запровадження щодо одержавленого місцевого самоврядування радянської моделі планової економіки і централізованого бюджетного фінансування, яка охопила і місцеві бюджети; 7 період (1991 - 2020 рр.) - становлення, розвиток і реформування фінансової бази розвитку місцевого самоврядування та розвитку регіонів на засадах бюджетної децентралізації. Досліджені основні періоди утвердження, розвитку та модернізації місцевих бюджетів у незалежній Україні (1991-2020 pp.).

Ключові слова: місцеві фінанси, місцевий бюджет, місцеве самоврядування, реформа місцевого самоврядування, фінансова децентралізація, доходи місцевого бюджету.

Fedorenko Vladislav Leonidovich Doctor of Law, Professor, Director of the Research Center for Forensic Examination on Intellectual Property of the Ministry of Justice of Ukraine, Honored Lawyer of Ukraine, 26, L. Ukrainka Boulevard, office 501, Kyiv, 01133; fedorenko900@gmail.com; +38 0445921401 , https://orcid.org/0000-0001-5902-1226

Fedorenko Tetyana Anatoliivna Postgraduate Student of the Department of Social and Humanitarian Policy, National Academy of the Public Administration under the President of Ukraine; doctor of the highest category Bogomolets National Medical University (Kyiv, Ukraine), e-mail: tf-doctor@ukr.net, https://orcid.org/0000-0003-1175-6404 


\title{
THE GENESIS OF LEGAL REGULATION OF LOCAL BUDGETS IN UKRAINE: FROM THE VIKINGS - TO MODERN LOCAL GOVERNMENT REFORM ON THE BASIS OF FINANCIAL DECENTRALIZATION
}

\begin{abstract}
The publication examines the problems of leakage of local finances and local budgets in Ukraine since the establishment of the Principality of Kiev in the IX-X centuries. - to the ongoing reform of local self-government in Ukraine on the basis of financial decentralization.

The genesis of local finances and budgets in Ukrainian was periodized and the following seven periods were singled out and characterized: 1 period (VIII-XIII centuries) - formation of the early feudal financial system of the Kiev Principality (Russia) on the basis of the Varangian flax system and various fees and tributes Russians began to gather not only princes and boyars, but also metropolitans; 2nd period (XIII-XVI centuries) - the introduction in the Kiev, Galicia-Volyn and other slavic principalities of the Tatar-Horde system of finance, based on the collection of "tithes" (tithe tax collection) of all property and income of "men" (heads of "yards"), first by the khan's baskaks, and later by the grand dukes and metropolitans, who used part of what they collected to secure their own local budgets; introduction in the Ukrainian lands of the budget system of the Grand Duchy of Lithuania, and later of the Kingdom of Poland and the Commonwealth, which ignored the needs for the development of local self-government in Ukraine; 3rd period (XVI-XVIII centuries) - Cossack-Hetman model of local budgets, under which the population continued to collect tithes and other fees, tax and duties, and the budget of the Zaporozhian Army alone (sometimes, together with the officer) managed the hetman; introduction, in order to separate public finances ("treasure") and the hetman's treasury, the position of treasurer ("minister of finance, duties and taxes") in the Constitution of P. Orlyk in 1710; 4th period (XVIII - early XX centuries) - the destruction of Catherine II of the Zaporozhian Sich and the Cossack-Hetman financial system and the spread to the Ukrainian lands of financial and budgetary systems of the Russian, Austro-Hungarian and Otaman (Southern Ukraine) empires and Romania (Bukovina), which provided funding for the regions on a final basis; 5th period (1917-1922) - incomplete formation of the system of local budgets during the national revolution (UPR, ZUNR, Hetmanate, Directory); 6 period (1922 - 1991) - the inclusion of Ukraine in the former Soviet Union and the introduction of the state model of state-owned local Soviet planned economy and centralized budget financing, which included local budgets; 7 period (1991 - 2020) - the formation, development and reform of the financial base of local government and regional development on the basis of budget
\end{abstract}


decentralization. The main periods of approval, development and modernization of local budgets in independent Ukraine (1991-2020) are studied.

Key words: local finances, local budget, local self-government, local selfgovernment reform, financial decentralization, local budget revenues

Постановка проблема. Місцеві бюджети, як фінансова основа регіонального розвитку України, отримали свій належний та подальший розвиток насамперед за часів незалежності України, із започаткуванням реформи місцевого самоврядування на засадах децентралізації та субсидіарності (2014-2020 роки). Важливим складником цієї реформи $\epsilon$ фінансова децентралізація та утвердження владоспроможних громад, а також посилення фінансового потенціалу розвитку територіальних громад і регіонів в Україні.

Разом із тим, помилковим було б вважати, що місцеві бюджети, як фінансова основа регіонального розвитку України $\epsilon$ ноу-хау сьогодення. Визнаючи той факт, що лише у незалежній, демократичній, правовій державі місцеве самоврядування отримує найбільш сприятливі умови для свого всебічного розвитку, відзначимо, що місцеве бюджети, як важлива складова місцевого самоврядування та регіонального розвитку, мають глибокі історичні витоки, що забезпечує тяглість у часі досліджуваної нами проблематики.

Аналіз останніх публікацій за проблематикою. Проблематика генезису місцевих фінансів і місцевих бюджетів, зокрема, в контексті процесів реформування місцевого самоврядування на принципах децентралізації та субсидіарності, на сьогодні досліджується в контексті історичної (М. Владімірський-Буданов [1], М. Дьяконов [2], Н. Полонська-Василенко [3, 4] й ін.), фінансової (Т. Бондарук [5] і ін.), та економічної (А. Чинчик [6] й ін.) науки, конституційного та муніципального права (М. Баймуратов, О. Батанов, Н. Мішина, В. Федоренко, О. Черниженко [7, 8, 9, 10] і ін.), інших соціогуманітарних наук.

Історія становлення та розвитку місцевих фінансів в Україні на різних етапах вітчизняного державотворення буде неповною без аналізу відповідних історичних джерел. У контексті предмету цього дослідження заслуговують на увагу як нормативно-правові джерела (договори руських князів, Руська правда, Конституція Пилипа Орлика 1710 року та ін.), так і монографічні дослідження проблематики місцевих фінансів на Українських землях, проведені в XVIII - на поч. XX ст. Зокрема, це наукові розвідки Ю. Гегамейстера «Розвідки про фінанси давньої Росії» (1833р.) [11] та Ф. Морошкіна «Про володіння за початками Російського законодавства» (1837р.) [12], О. Васильчикова «Про 
самоврядування. Порівняльний огляд Російських i iноземних земських i громадських установ» (1870р.) [13], навчальні видання С. Іловайського «Підручник фінансового права» (1904) [15] та І. Озєрова «Основи фінансової науки» (1908р.), 2-й том якої присвячено проблематиці місцевих фінансів [16] та ін.

Метою статті $\epsilon$ виявлення, аналіз і систематизація основних періодів утвердження та розвитку місцевих бюджетів в Україні й їх правового забезпечення з часів утвердження Київського Князівства (Русі) - до реформи місцевого самоврядування та територіальної організації влади на засадах децентралізації та субсидіарності в 2014-2020 роках, а також формування наукових знань про логіку подальшого правового забезпечення процесу фінансової децентралізації в Україні.

Виклад основного матеріалу. Беручи до уваги проблематику походження місцевих фінансів і місцевих бюджетів, слід звернути увагу на той феномен, що елементи місцевої самоврядності передують утвердженню перших держав. До того ж, на окремих етапах історичного розвитку України місцеве самоврядування складало єдину основу публічної влади для українських земель. Разом із тим, місцеве самоврядування, яке О. Васильчиков визначив як «... такий порядок внутрішнього управління, за якого місчеві справи і посади завідуються й займаються місцевими жителями - земськими обивателями» $[13$, с. 1], отримує свій системний розвиток саме із становленням i розвитком держави та іiі інститутів. До останніх слід віднести і державну бюджетно-фінансову систему. Адже, не зважаючи на самостійну природу місцевих фінансів і місцевих бюджетів, їх зміцнення та розвиток безпосередньо залежить від рівня ефективності та надійності державних бюджетнофінансових систем.

Проблема походження етногенезу та державотворення слов'янських народів Східної та Південної Європи залишається однією 3 найбільш дискусійних. Щодо неї на сьогодні маємо чимало міфів і ретроспективних політизованих оцінок. Як пише Л. Залізняк, «... українська історіографія, щзо виросла на самоусвідомленні україниями свого генетичного зв'язку 3 населенням Південної Русі, традиційно вважала княжий Київ украӥнським («История Русов», 1846 та ін.). ... Генетичним підгрунтям населення Київської Русі були південноруські літописні племена (деревляни, поляни, волиняни, хорвати, уличі, тивериі), які залишили археологічні пам'ятки лука-райковецької культури VIII-IX cm.» [17, с. 458]. Утім, нині маємо і множину інших теорій і підходДо прикладу, Г. Кольб у другій пол. ХІХ ст. писав, що слов’янські народи стали відомими Західній Європі з VI ст. «Ti, щзо населяли Cхід, в особливості 
Північний Схід Германї, поділялися на множину племен: оботріти, поморяни, древляни, поляни, серби, чехи, морави і венеди. ... Далі на Схід жили ляхи (поляки), яких ми водночас знаємо лище за свідченнями X сm., в кінці якого вони прийняли християнство. Дещуо раніше починається історія Руссів» [18, с. 23], стверджував учений.

Один із дослідників Давньої Русі М. Дьяконов, посилаючись на Ф. Гізо, який стверджував, що в дитинстві цивілізації не могло бути великих держав, писав про те, що Давня Русь являла собою «велику кількість невеликих держав, кордони яких піддавались постійним коливанням. ... Ці давньоруські держави носять назви «земель», «княжінь», «волостей», «уїздів», «вотчин». ... Літописи нерідко згадують про різні землі: Киїську, Галицьку, Чернігівську, Муромську, Ростовську та ін.» [19, с. 62].

Разом із тим, беручи до уваги норманську теорію походження державності в слов'янських народів, можна погодитись із думкою С. Плохія про те, що у кін. IX-X ст., Русь була «одним із багатьох «державотворчих» починань норманів (урманів) у середньовічній Свропі» [20, с. 14]. Тобто, перші князівства слов'ян, по-суті, були заморськими ленами безземельних молодших синів варязьких (норманських) конунгів («конунг», «князь» - «кінна людина»; «варяг» - «білий вершник» [21, с. 995-996]).

Окремі вчені вважали, що варязькі племена були етнічною основою Русі. Так, М. Владімірський-Буданов писав щодо цього таке: «... Руссю називали одне 3 варязьких племен; інші племена тієї ж національності були: Шведи («Свеї»), Нормани («Урмани» - Норвежці), Англійці (Англяни) і Готи. «I від тих Варягів прозвалася Руська земля»» [1, с. 276]. Наведена ідея М. Владімірського-Буданова вбачається доволі дискусійною. Але, очевидним є той факт, що до XI ст. варяги мали важливий вплив на становлення державності та фінансової системи Київського Князівства.

Зокрема, дослідник державного права Швеції П. Димша понад століття тому писав про цей тренд слов’янського державотворення наступне:

«Постання на престол Великого Князя Володимира, якого в шведських літописах називали Вольдемаром, пов'язане з ім'ям Варягів; вони то й допомогли Великому Князю зайняти в 980 роцуі Київський престол. Син Володимира Ярослав також звертався за допомогою до Варягів; у подальшому він вступив до шлюбу з варязькою принцесою Інгегерд, дочкою короля Олафа. ... Тут прожив також хоробрий Інге, пізніше король Шведський, своє дитинство та юні роки. Такі оповіді літопису про постійні взаємні відносини наших зі иведами в ті віддалені часи» [22, с. 21]. 
Під «нашими» П. Димша, звичайно ж, розуміє «предків росіян», а не українців. Але, визнання «норманської теорії» походження Київського Князівства на поч. ХX ст. російським правником вбачається знаковим. Адже, боротьба у XVIII ст. офіційного ідеолога Російської Імперії М. Ломоносова 3 відомою «теорією Байєра-Міллера-Шльоцера» завершилась офіційним запереченням участі варягів у формуванні Київського Князівства, а сама категорія «Русь» почала безпідставно пов'язуватися, а пізніше навіть ототожнюватися 3 «Росією».

Уникаючи більш глибоких наукових розвідок щодо особливостей i хронологічних рамок походження державності в слов'янських народів, відзначимо, що Київське та інші князівства загалом були співставними 3 багатьма іншими історичними державами Європи XI-X ст. i мали спільні проблеми: від охорони кордонів - до формування власних бюджетів. Хоча, згадок про фінансову основу княжої влади у цей період донині дійшло не багато.

Відома українська дослідниця проблематики місцевих бюджетів Т. Бондарук обгрунтовує, що утвердженню місцевих фінансів на Українських землях передувало формування місцевого самоврядування за часів «Руської Правди» Ярослава Мудрого, коли було запроваджене місцеве звичаєве право. Як пише вчена: «I хоча на той час щзе про місизеві фінанси не йилося, проте адміністративно-господарські правовідносини, необхідні для ӥх функціонування, були створені» [5, с. 49]. Загалом погоджуючись із позицією про те, що місцеві фінанси і місцеві бюджети 3’являються там i тоді, де утверджується місцеве самоврядування, відзначимо, що питання про фінанси i оподаткування на Українських землях виникли разом із утвердженням перших слов'янських князів.

Беручи до увагу вже згадувану «Норманську теорію» походження державності в східних слов’ян, логічним було б передбачити, що варяги мали покладати на руські князівства, включаючи і Київське, данину. Але, як писав у cер. XIX ст. Ю. Гегемейстер щодо цього питання, «Рід нових Варязьких володарів був не підкорювачем туземців, ні рівним їм. Руські Князі, покликані на захист від зовнішніх ворогів, не змогли накласти на Слов'ян данину, якій піддавалися переможені народи, але вимагали від них, у винагороду за свою працю, кошти на утримання, $і$ вводячи власні вітчизняні установи, ввели явища, дивні для настільки нової Держави» [11, с. 2].

Якими ж були «дивні» новели варягів (норманів) у сфері місцевих фінансів у Київській Русі? Очевидно, що йдеться про повинності та наймання варягів для ведення воєн, охорони від нападів з боку інших князів, шляхом їх 
утримання, а також про данину «від двору», про яку згадує іще Нестор Літописець. Йдеться про відкуп Киян від варягів, які підтримували Володимира при зайнятті ним Київського престолу, у дві гривні «від чоловіка» (980р.) [11, Додаток № 1].

3 часом данина (від слова «давати») стає фінансовою та матеріальнотехнічною основою князівської влади у слов’ян. Ї̈̈ брали «з вогнища», «з димаря», «з двору», «від плугу» тощо. Данина з 883 по 1246 рік збиралася «по чорній куниці з людини» (883р.), «по илягу» (885 р.), по «від мужа 4 куни, від старост 5 гривень, від бояр 18 (80) гривень» (1018р.), по «шкурі білого медведя, бобра, кунищі, тхора і чорної лисиці з людиною» (1246р.) [11, Додаток № 1].

У Архангелських списках також згадується, що князь Олег брав 3 древлян дань «з чоловіка» («мужа»). При цьому, як зазначає Ю. Гагамейстер, ішлось не про все доросле чоловіче населення, а про глав родин («дворів»). Із часом ця данина стає усталеною, й збирається з міста в цілому. Зокрема, Нестор пише про збирання для варягів з Новгороду «гривень 300 на літо» [11, с. 14-15]. Цікаво Ю. Гагамейстер описує й саму процедуру збору податків у слов’янських князівствах: «Руські Князі проводили усе літо на війні, а решту року, починаючи із листопада місяця, кочували вони, за свідченням Косятнтина Багрянородного (de administrando imperi cap. IX) 3 двором і дружиною своєю, продовольствуючи себе i наближених своїх за рахунок підкорених народів i збираючи при цьому із них встановлену данину» [11, с. 15].

Окрім того, джерелом князівських доходів також були оброки і уроки, зміст яких у найбільш загальному вигляді зводився до особистих повинностей i проведення безоплатних робіт. До цих джерел також слід віднести військову добичу, князівську долю від контрибуцій. Значний відсоток 3 данини залишали для власних потреб княжі намісники. До прикладу, «з 5000 гривень, які платили новгородиі, Ярославль, будучи Намісником тамошнім, отримував 1000; Ольга відправляла третю частину збираної нею у древлян данини в своє володіння в Вишгород» [11, с. 28].

Після хрещення в IX ст. Князя Володимира на Русі з'являється новий соціально-політичний i фінансово-економічний прошарок тодішнього суспільства - духовенство. Новим механізмом поповнення бюджетів 3 цього часу стали віри - грошові штрафи за вбивство людини, відомі як інститут композицій (з лат. compositio - «примирення»), який передбачав примирення через виплату викупів за скоєний злочин. Зазначене зумовлюється тим, що після запровадження християнства в слов'ян церква «сурово засуджувала «язицницьке» позбавлення життя «ближнього»» [23, с. 194], а також негативно 
ставилась до кровної помсти. Застосування штрафів за вбивство передбачало відрахування з цього штрафу судового збору.

Князівські бюджети також поповнювали судові збори, податки і митні збори. Щодо останніх, то «вони спочатку складалися з мита, яке сплачувалося торгівияли чи подорожуючими власникам землі за утримання доріг і ринків, $i$ за право їхати по першим чи зупинятися на останніх. Тому, збори цуі належали не верховній владі, $і$ будь-який боярин, будь-який монастир присвоював собі ие право. Таке ж зустрічається в Середні віки і в Західній Свропі» [11, с. 44-45]. 3 цієї розлогої цитати можна зробити висновок, що мито стало важливим джерелом для власних доходів місцевих бюджетів. Зокрема, т.3. «вагові гроші», які збиралися в Новгороді, починаючи із XII ст., як мито з певної ваги товару, сприяло розвитку торгівельних портів i міст, де відбувалися торги i проводилися ярмарки.

До джерел власних доходів тогочасних місцевих бюджетів слід віднести також надзвичайні податки, які «розкладалися здається на добровільний розсуд начальників, чи за розпорядженням суспільства» [11, с. 48]. Натомість, інститут данини втратив у цей час своє значення. Лише Новгород продовжував нерегулярно збирати данину з окремих фінських племен. А за короткий час слов'янські племена, як відомо, самі стали об'єктом завоювання й платниками данини.

Період володарювання на українських землях татарів у XIII-XVI ст. призвів до втрати державності та встановлення системи фактичного васалітету над найбільшим серед слов’ян Київським Князівством, яке було трансформоване в Київську Метрополію. Твердження сучасників про те, що татарська навала та бездержавність «не перервали етнокультурний розвиток територій між Карпатами та Дніпром і тяглість етнічної самосвідомості українців» [17, с. 468] вбачається патріотичною, але не зовсім об'єктивною.

Як відомо, з появою монголів у світі їх власна назва-топонім постійно змінювалася. У східних джерелах їх називали «улус Берке», «улус Узбека»; у європейських джерелах, у залежності від політичного контексту, знаходимо назву «королівство татар», «володіння імператора (король) татар», або ж поліетнічне - «татари»; у слов’янських літописах - це «татаро-монголи», «татаро-монгольське іго», а також «Золота Орда» та за низкою менших, місцевих орд (Мамаєва, Перекопська, Білгородська) [24, с. 8-13].

У 1239 р. нащадок Чінгісхана хан Батий почав завойовувати українські землі. Один загін татар взяв «копьем» (штурмом) і «избил» Переяслів; інший оточив «в силе тяжце» Чернігів і розбив військо Мстислава Глібовича. У 1240 р. було взято в облогу та зруйновано Київ, який перетворився на «мізерне» 
місто в 200 дворів. Батий віддав Київ Володимиро-Суздальському князю Ярославу Всеволодовичу, а по його смерті - Олександру Невському. Утім, жоден із них не в’їздив до Києва [25, с. 49]. Можемо передбачити, що втрата інтересу до Києва інших слов'янських князів, які вступили у договірні стосунки 3 татарами, призвела до послаблення світської влади на території Київського Князівства на користь влади духовної. Про це, зокрема, свідчить і факт отримання ханських ярликів Київськими метрополитами, які будуть проаналізовані далі.

Татарське нашестя на Українські землі в XIII ст., з одного боку, стало можливим через конфлікти між князями «... в Галичі, на Волині, в Київі ц̌ Курську, Новгороді ц̌ Володимирі, Смоленську та Чернігові» [26, с. 304], а 3 іншого т.з. «темні віки» зруйнували публічну владу тогочасних слов'янських князів, знищили їх бюджетно-фінансову систему. Утім, 3 точки зору фінансового та податкового права, у цей час спостерігаємо й тенденція щодо упорядкування та уніфікації щонайменше на два 3 половиною століття тогочасної податкової системи.

Зазначимо, що татарська адміністрація запровадила для підкорених слов’янських народів, включаючи українців, досить зрозумілу і універсальну систему збору податків. Як пише Ю. Гагамейстер, «татари здається прийняли за правило, щуо десята частина всього майна, мита і навіть люди у підкорених ними народів мали належати їм, щуо узгоджується й із тією обставиною, щуо військо їх складалося частково із підвладних їм народів ... Татари все ж у подальшому переконалися в незручності десятинного податку, і тому почали брати подушні гроші, переписавши в оклад всі класи людей, крім духовенства. Таким чином $і$ знатні (люди - автор.), як наприклад бояри, підтримали спочатку изі податки, але вони швидко встигли полегшити їx, $i$ навіть, через подарунки, зовсім звільнилися від них. Тому, весь тягар залишався на черні; над 10, 100, 1000 людей визначені були татарами наглядачі, які після збору податків віддавали їх відкупщчикам чи князівським чиновникам» [11, с. 56-57]. Щодо особливої ролі духовенства за часів татарської орди, то в текстах Ханських ярликів, які містяться в хрестоматії «Зібранні найважливіших пам'ятників 3 історії давнього Руського права» (1859 р.), йдеться про умови виплати Київськими метрополитами данини за текстами ханських ярликів. Зокрема, в Ярлику, хана Бердебека Метрополиту Київському Олексію в 1357 р., йдеться про «данину» й «збір», який мали сплачуватися «Татарському улусному й ратному князеві Бердебеку», але їх розміри не уточнювалися. Натомість, для сплати данини i зборів на користь татар, Метрополитові Київському ханом жалувалося право на збір із церковних домів, і городів, i 
виноградників, і церковних людей. При цьому, в силу віротерпимості тодішньої релігії татар, останні зобов'язували молотись за них Метрополита Київського та «церковний люд», та гарантували їм свій захист [27, с. 426-427].

У свою чергу, «татарські відкупщики» (баскаки), за свідченням того ж Ю. Гагамейстера, «були торгівиями різних народів, Хівінці, Козари, Жиди, і не мали інших видів, окрім власної вигоди ...»[11, с. 58]. 3 часом, великі князі витіснили і підмінили собою баскаків і самі збирали данину, яку відправляли у Золоту Орду.

Таким чином, можемо зробити висновок, що біля трьох століть, 3 середини XIII ст. - до кін. XV ст., Київське та інші князівства та метрополії були окуповані татарської ордою та охоплені прийнятою в ній системою «десятинного» оподаткування. 3 часом, відтіснивши баскаків, слов’янські князі i метрополити, по-суті, стали частиною інституційної татаро-ординської податкової системи, і отримували із неї відому власну вигоду («... самі хани докоряли великим князям в тому, щуо вони збирали данину з підданих своїх непорівняно більшу, ніж платили до Орди ...» [11, с. 136]), нерідко зловживаючи своїми правами «відкупщиків», та фактично знищили місцеві бюджети тодішніх громад. Разом із тим, великі князі й метрополити за «темних віків» створили фінансову основу для абсолютизацію своєї влади.

Об’єктом татарської навали стало й Галицько-Волинське князівство на чолі 3 Данилом Галицьким, який у 1245-1246 році був змушений визнати залежність від Золотої Орди й отримати ярлик на княжіння, хоча від боротьби iз татарами не відмовився. У 1253 році Данило погодився на унію 3 католицькою церквою та був коронованим папою Римським. Не отримавши допомоги у боротьбі Данило відмовився від унії й зі своїми силами повстав проти татарського воєводи Куремси. Але, під натиском нового татарського воєводи Бурандая Галицько-Волинське князівство в 1256-1259 роках остаточно потрапило під вплив Золотої Орди і перейшло на систему збору данини, охарактеризовану вище щодо Київського Князівства [25, с. 52-55].

Пізніше, починаючи iз XIV ст., фінансові основи місцевого самоврядування та регіонального розвитку в Україні, за умови відсутності міжнародної правосуб’єктності як національної держави, перебували під впливом сусідніх держав. Відносно сприятливі умови для регіонального розвитку Українських земель стало перебування їх у складі Великого Князівства Литовського (толерантність до мови, культури і віросповідання). Як відомо, за часів князя Гедиміна в 1340 році вплив Великого Князівства Литовського або ж Литовсько-Руського князівства поширився на Галичину та Волинь. 
За свідченням А. Чинчика, «За часів Великого Князівства Литовського зберігалась иерковна «десятина», податкові пільги для вищих верств населення, поширеними були безкоштовні роботи селян на задоволення потреб князя і шляхти. Селяни залишались основним платником податків» [6. с. 64]. Але, після союзу литовського князя Ягайла з ханом Мамаєм та в силу поразки останнього в Куликовській битві 1380 року від Московського князя Дмитра Івановича (Донського), а також через зміцнення Тевтонського Ордену, позиції Великого Князівства Литовського похитнулися. Внаслідок укладення в 1385 році Кревської унії та шлюбу в наступному році Ягайла з королевою Польщі Ядвігою, литовські й руські землі були приєднані до Корони Польської. У подальшому Польська Корона та Велике Князівство Литовське утворили у 1569 році Річ Посполиту, до складу якої ввійшли Галичина, Холмщина, Волинь, Поділля, Брацлавщина, Київщина та Підляшшя. Ці українські землі почали щедро роздаватися Польською Короною власним магнатам і «королев'ятам», а населення було обкладене обтяжливими податками [3, с. 315, 343]

Певні преференції мали лише Українські міста, наділені Магдебурзьким правом (Magdeburger Weichbildrecht), відомим у Європі з кін. XII ст. На теренах України Магдебургзьке право у XIV-XVIII ст. було проголошено у Житомирі, Кам'янець-Подільському, Києві, Кременці, Львові, Луцьку, Мукачеві, Новгород-Сіверському, Пирятині, Полтаві, Прилуках і інших містах. Власне, ці «вільні міста» могли формувати відносно самостійні міські бюджети, які забезпечували їх життєдіяльність і розвиток.

Інша частина України, Правобережна, за часів Хмельниччини, перебувала в стані національно-визвольної війни, яку іще називали козацькою революцією, та яка «... завершилась у вересні 1676 p. 3 припиненням функиіонування державних інституцій Правобережної Гетьманщини» [28, с. 353]. Закономірно, що перманентні козацькі війни і революції, драматичний вибір союзників між Москвою, Варшавою та Портою, не створили сприятливих умов для формування ефективних фінансових основ місцевого самоврядування в Україні.

Н. Полонська-Василенко так пише про тогочасну фінансову систему України: «Фінанси Украӥни-Гетьманщини в XVII cm. були неподільно зв'язані з господарством гетьмана і мали натуральний характер. В основі державного господарства лежали реквізовані в польської иляхти землі, які стали власністю Війська Запорізького - давні «королівщини», що служсили на утримання державних установ та урядовців. Селяни, щчо мешкали на цих землях, платили податки скарбові. 3 иьього фонду приділяли рангові землі старшині і урядовиям ... Постійні прибутки йшли від податків. За податковою 
системою Гетьманщиини оподатковувалось найбільи незаможну людність селян і міщзан, а козаки та монастирі податків не платили» [4, с. 190].

Отже, фінансово-податкову систему Гетьманщини, на наш погляд, складно вважати достатньою, а тим більше ефективною базою для розвитку місцевого самоврядування та регіонального розвитку України, а також для забезпечення діяльності національних органів публічної влади на місцях, за винятком Гетьмана та гетьманських старшин і полковників. Спроби Гетьмана Брюховецького роз'єднати майно Гетьмана і Запорізької Січі не мали успіху. Посада генерального підскарбія, як керівника державних фінансів, запроваджена цим гетьманом відродилася лише в 1728 році.

Драматичної поразки армії Швеції та їх союзників - козаків, під керівництвом Гетьмана I. Мазепи, у Північній війні надовго відтермінувала реалізацію мрії українців про власну національну державу та бюджетнофінансову систему. Показово, що аж до краху Російської імперії І. Мазепа описувався у всіх наукових розвідках проімперських учених 3 неприхованою ворожнечею та презирством. Для прикладу, відомий історик Й. Павловський так описував переправу I. Мазепи і війська Карла XII у своїй роботі, присвяченій 200 річчю Полтавської битви: «Периим переправився Мазепа, якому треба було поспішати $i$ потурбуватися про власний порятунок, не дочікуючись результатів перемовин з королем. Він встиг захопити з собою дві діжечки із золотом» [29, с. 95]. Російська історіографія містить і більш нищівні характеристики Гетьмана I. Мазепи, який намагався вибороти національну державність.

Після поразки Швеції в Північній війні Українські землі на тривалий час потрапила під вплив Росії. Як звертає увагу А. Чинчик, «Показовим моментом у податковій політиці Петра I було введення 1724 року єдиного грошового та подушного податків. Згодом відбувалася поступова монетизація податків, тобто повна відмова від натуральних їх форм» [6, с. 53-54]. Проблема формування власних доходів місцевих бюджетів в Україні та фінансового забезпечення розвитку Правобережної України полягала в їх повному ігноруванні Російською Імперією.

Давня проблема поєднання державних і приватних фондів бюджету після смерті Гетьмана I. Мазепи поставила під удар фінансування уряду в екзилі Пилипа Орлика. Як пише Н. Полонська-Василенко, П. Орлик, «обраний на гетьмана ввесь час витрачав на державні справи свої власні кошти» [4, с. 191]. Це вплинуло й на текст Конституції Пилипа Орлика 1710 року, в якій відновлювався уряд підскарбія, а гетьман обмежувався в правах розпоряджатися «добром військовим» [30]. Але, Катерина II в XVIII ст. не лише 
зруйнувала Запорізьку Січ, а i знищила всі інші паростки національної державності та місцевого самоврядування в Україні. Із 1781 року Гетьманщину було поділено на 3 намісництва: Київське, Чернігівське та Новгород-Сіверське. Малоросійську колегію та всі спеціальні установи з «українських питань» були скасовані.

У XIX ст. у Європі (Англія, Німеччина, Франція, Росія) та США сформувалася теорія та практика місцевого самоврядування, а також теоретикометодологічні положення щодо місцевого оподаткування, прототип сучасної бюджетної системи, модифікацію якої використовували і продовжують використовувати багато держав світу. Підставою для розвитку місцевих бюджетів і оподаткування став розвиток місцевого самоврядування в більшості тогочасних європейських держав, включаючи і Російську імперію, до складу якої входила значна частина України.

Український учений С. Іловайський на поч. XX ст. так описував місцеві фінанси: «Зазвичай держава доручає певні функиії громадської діяльності місиевим союзам, в яких визначається й відкривається сфера для діяльності останніх. Жодне місцеве господарство не може бути само по собі суб'єктом фінансового верховенства. Якщзо воно може встановлювати податки $і$ різні збори та приймати примусові заходи щуодо їх стягнення, то лише у силу повноважень, наданих йому державою» [15, с. 366].

У другій пол. XIX ст. реформи місцевого самоврядування мали успіх і в Російській імперії, чому посприяло скасування Маніфестом 1861 p. кріпосництва та проведення наступного року селянської реформи. В 1862 році також було проведено реформу фінансового господарства імперії, результатом якої стало призначення міністра фінансів і концентрацію в його руках повноти державного управління фінансами.

Після земської реформи 1864 року, в основу якої було покладено Положення про земські заклади, у 34 губерніях російської імперії створюються земства - органи місцевого самоврядування, які мали демократичний характер [5, с. 51]. Вони мали право оподатковувати нерухоме майно в містах та повітах та формувати інші земські збори, до яких належали акцизи на заклади 3 продажу напоїв та трактири, судове мито, збори за керування переправами, шляхами, свідоцтво на промислову продукцію та патенти заводів, та ін. Загальний закон визначав максимальні ставки в межах яких земства самостійно встановлювали земські збори. Крім того земства мали право встановлювати земські повинності, які мали цільовий характер та фінансували лікарні, школи, місцеву поліцію та інші соціально значимі сфери життя. 
У 90-х роках XIX ст. повноваження земств було обмежене, бо частина земських повинностей встановлювалася не земствами, а державою. До того ж, як пише Н. Полонська-Василенко, утворення земств у 1864 році відбулося лише на Лівобережній і Південній Україні, тоді як «на Правобережжі, яке тільки пережило польське повстання, земство поширилось щойно в 1911 році, бо уряд боявся дати можливість польському шляхетству впливати на самоуправління цього краю» [4, с. 315].

До початку XX ст. фінансові основи місцевого самоврядування та фінансового розвитку на Українських землях були виснажені сусідніми імперіями, які не залишали для України жодних шансів на відродження. У цьому сенсі можемо погодитись із А. Чинчиком, який пише: « $У$ nеріод панування Речі Посполитої, подальшого поневолення Російською імперією та Австро-Угорської монархією, податковий тиск на населення продовжував бути дуже високим» [6, с. 64]. Закономірно, що тогочасні доволі жорсткі централізовані бюджетно-фінансові й фіскальні системи, як і відсутність національної державності, стримували розвиток місцевого самоврядування в Україні.

Земські збори та повинності було скасовано в 1917-1918 рр., після ліквідації земського місцевого самоврядування. Але, Перша світова війна, а надалі й більшовицька революція призвели до краху Російської імперії, яка через свою архаїчність не змогла відповісти на виклики модернізації XX ст., в тому числі, й у частині формування ефективних місцевих бюджетів.

У період національно-визвольної революції 1917-1922 років УНР, ЗУНР, Гетьманат П. Скоропадського та Директорія, в процесі національного державотворення створювали міністерства, які відали фінансами і податками, у складі урядів. Це, для прикладу, було Міністерство фінансів у складі Ради народних міністрів УНР, що існувала в січні-квітні 1918 року та ін. Разом із тим, нетривалий період національної державності не дозволив сформувати стабільну фінансову базу для розвитку місцевого самоврядування та регіонального розвитку.

Після більшовицької експансії та встановлення радянської влади в Україні, з їі наступним включенням у 1922 року до складу СРСР, було демонтовано національну фінансово-бюджетну систему, яка почала утверджуватися в Україні в 1917-1922 роках. Після НЕПУ (1922-1927 рр.) СРСР вдався до планової економіки та розбудови жорстко централізованої системи «рад всіх рівнів», які формувалися на безальтернативних виборах і діяли в складі радянського державно-партійного апарату. Цей період розвитку фінансових основ місцевого самоврядування та регіонального розвитку 
передбачав забезпечення базових потреб громадян при їх максимальному оподаткуванню.

Певна лібералізація радянської фінансової системи відбулася після т.з. «Перебудови», але значних змін для розвитку місцевого самоврядування вона не принесли. Утім, керівництво радянських союзних і автономних республік почали в кін. 90-х років XX ст. готувались до радикальних змін і все частіше залишали значну частину доходів в своїх республіканських бюджетах. Ці фінансові ресурси, в одних випадках, були розграбовані після розпаду СРСР, а в інших - використані для становлення національної державності пострадянських республік у 1991 році.

Реформа місцевого самоврядування в незалежній Україні також має власну тривалу історію [8, с. 582-592]. Лише у період незалежності (1991-2020 рр.) спроби реформування місцевого самоврядування в Україні здійснювалися декілька разів. Використовуючи попередні напрацювання, та здійснючи їх екстраполяцію на генезис бюджетів місцевого самоврядування та регіонального розвитку, можна виявити наступні п’ять основних етапів:

- 1991-1996 pp. - формування конституційної моделі місцевого самоврядування в незалежній Україні, трансформація радянської системи «рад всіх рівнів» у пострадянську громадівську модель місцевого самоврядування, спочатку в Конституційному Договорі [31], який став альтернативою для примирення парламенту i глави держави після провалу низки проектів Конституції України i проекту Закону «Про державну владу та місцеве самоврядування в Україні, з одночасним збереженням пострадянської моделі формування місцевих бюджетів, яка передбачала їх перерозподіл з центру;

- 1996-2004 pp. - закріплення засад місцевого самоврядування в Конституції (ст. 142 і ін.) [32] та законах України, зокрема в Законі України «Про місцеве самоврядування в Україні» [33], та розбудова громадівської моделі місцевого самоврядування в Україні й запровадження окремих елементів бюджетної децентралізації;

- 2004-2014 рр. - спроби реформування місцевого самоврядування шляхом прийняття законопроекту про внесення змін до Конституції України щодо удосконалення системи місцевого самоврядування (реєстр. № 3207-1), інші ініціативи щодо посилення владоспроможності територіальних громад i регіонів, включаючи проекти про запровадження в окремих регіонах зон вільної торгівлі (до прикладу, ідея запровадження porto franco в порту Одеси);

- 2014-2019 рр. - започаткування після Революції гідності 2014 року системної реформи місцевого самоврядування та територіальної організації 
публічної влади на засадах децентралізації та субсидіарності [34] та невдала спроба їі закріплення в Законі про внесення змін до Конституції України (щодо децентралізації (№ 2217a) [35]; напрацювання законів про співробітництво територіальних громад [36] та їх добровільне об’єднання [37], а також прийняття закону [38] та стратегій i програм регіонального розвитку й їх реалізація;

- 2019-2020 рр. - переосмислення новообраним Президентом України і Верховною Радою України IX скликання здобутків реформи місцевого самоврядування; курс на завершення процесу утворення в Україні ОТГ шляхом затвердження Кабміном перспективних планів розвитку територій громад областей до кін. 2020 року, а також на поглиблення фінансової децентралізації територіальних громад i регіонів; конституційні ініціативи щодо іiі продовження на регіональному рівні в кін. 2019 року [39] та на поч. 2020 року та розроблення механізмів поновлення та посилення власних доходів місцевих бюджетів після пандемії COVID-2019, як фінансової та матеріально-технічної основи розвитку регіонів.

Висновки і перспективи подальших досліджень. Мета, завдання та обсяг однієї статті не дозволяють вичерпно розкрити проблематику генезису місцевих фінансів і бюджетів в Україні з найдавніших часів - до сьогодення. Кожен окремо взятий період генезису досліджуваного явища може бути предметом декількох подальших фундаментальних досліджень. Не всі 3 досліджуваних періодів розкриті пропорційно. Більша увага приділялася джерелам формування місцевих фінансів в Україні в IX-XV ст.ст. за варягів і татар, а також генезису місцевих фінансів і місцевих бюджетів у незалежній Україні (1991-2020 рр.).

Разом із тим, дослідження дозволило виявити і охарактеризувати сім основних періодів генезису фінансових основ місцевого самоврядування та регіонального розвитку на Українських землях із найдавніших часів - до сьогодення, а саме:

1 період (VIII-XIII ст.) - формування ранньофеодальної фінансової системи Київського Князівства (Русі) на базі варязької ленної системи та різних зборів і данини, які після хрещення Русі почали збирати не лише князі та бояри, а й метрополити;

2 період (XIII-XVI ст.) - запровадження в Київському, ГалицькоВолинському та інших слов'янських князівствах татаро-ординської системи фінансів, заснованої на збиранні «десятини» від всього майна i прибутків «мужів» (глав «дворів»), спочатку ханськими баскаками, а надалі - великими князями i метрополитами, які використовували частину зібраного для 
забезпечення власних місцевих бюджетів; запровадження в українських землях бюджетної системи Великого Князівства Литовського, а пізніше Польського Королівства та Речі Посполитої, які ігнорували потреби розвитку місцевого самоврядування в Україні;

3 період (XVI-XVIII ст.) - козацького-гетьманська модель місцевих бюджету, за якої з населення продовжувала збиратися десятина і інші збори та мита, а бюджетом Війська Запорізького одноособово (іноді, разом із старшиною) розпоряджався гетьман; запровадження, 3 метою розділення публічних фінансів («скарбу») і гетьманської казни, посади підскарбія («міністра фінансів, зборів і податків») у Конституції П. Орлика 1710 р.;

4 період (XVIII - поч. XX ст.) - руйнування Катериною II Запорізької Січі та козацько-гетьманської фінансової системи і поширення на Українські землі фінансово-бюджетних систем Російської, Австро-Угорської та Отаманської (Південь України) імперій та Румунії (Буковина), які забезпечували фінансування регіонів за остатковим принципом;

5 період (1917-1922 рр.) - незавершене формування системи місцевих бюджетів за доби національної революції (УНР, ЗУНР, Гетьманат, Директорія);

6 період (1922 - 1991 рр.) - включення України до складу колишнього СРСР та запровадження щодо одержавленого місцевого самоврядування радянської моделі планової економіки i централізованого бюджетного фінансування, яка охопила і місцеві бюджети;

7 період (1991 - 2020 рр.) - становлення, розвиток і реформування фінансової бази розвитку місцевого самоврядування та розвитку регіонів на засадах бюджетної децентралізації.

Досліджені основні періоди утвердження, розвитку та модернізації місцевих бюджетів у незалежній Україні (1991-2020рр.), очевидно, матимуть своє продовження. Так, у липні 2020 року, Верховна Рада України IX ст. дала старт подальшій реформі місцевого самоврядування, ліквідувавши 490 районів і утворивши 138. Укрупнення районів загалом сприятиме зміцненню фінансових основ і повновладдя територіальних громад і посиленню регіонів. Водночас, важливим завданням подальшої реформи місцевого самоврядування в Україні має стати збереження існуючої та розширення податкової бази місцевого самоврядування, як основи дохідної частини місцевих бюджетів.

\section{Лimepamypa:}

1. Владимирский-Буданов М.Ф. Обзор истории русского права. Изд-е седьмое. Петроград; Киев: Изд-е книжного магаз. Н.Я. Оглоблина, 1915. 699 с.

2. Дьяконов М. Очерки общественного и государственного строя Древней Руси. Изд. второе. С.-Петербург: Изд-е Юридического книжного склада «Право», 1908. 509 с. 
3. Полонська-Василенко Н. Історія України. В двох томах. I том (до пол. XVII сторіччя). Мюнхен: Українське вид-во, 1972. 591 с.

4. Полонська-Василенко Н. Історія України. В двох томах. II том (від пол. XVII сторіччя до 1923 року). Мюнхен: Українське вид-во, 1976. 599 с.

5. Бондарук Т.Г. Місцеве самоврядування та його фінансове забезпечення в Україні: монографія / НАН України ; Ін-т екон. та прогнозув. Київ: 2009. 608 с.; табл. рис.

6. Чинчик А.А. Розвиток доктрини опадаткування в українській економічній думці другої половини XIX - початку XX ст.: дисерт. канд. економ. наук за спец. 08.00.01. Львів, 2016. 244 c.

7. Батанов О.В. Муніципальна влада в Україні: проблеми теорії та практики: монографія. Відп. ред. М.О. Баймуратов. Київ: Юридична думка, 2010. 656 с.;

8. Федоренко В.Л. Конституційне право України: підручник; До 20-ої річниці Конституції України та 25-ої річниці незалежності України. Київ: Вид-во «Ліра», 2016. С. 573-614.;

9. Федоренко В.Л., Чернеженко О.М. Конституційні моделі місцевого самоврядування у державах-учасницях СС, Швейцарії та Україні / В.Л. Федоренко, О.М. Чернеженко: монограф; за ред. В.Л. Федоренка. Київ: Вид-во «Ліра», 2017. 288 с.;

10. Місцеве самоврядування в Україні та зарубіжних державах: порівняльно-правові аспекти: монограф. За ред.: О.В. Батанова, О.В. Марцеляка, А. Берлінгуера. Київ: Вид-во «Основа», 2020. С. 265-381 672 с.

11. Гегемейстер Ю.А. Розыскания о финансах древней России. С.-Петербург: При Императ. Акад. Наук, 1833. 247 с.; VIIIc.; VI додатків.

12. Морошкин Ф. О владении по началам Российского законодательства. Москва: В Университ. Типографии, 1837. 237 с.; II с.

13. Васильчиков А. О самоуправлении. Сравнительный обзор Русских и иностранных земских и общественных учреждений. С.-Петербург: Типограф. Э. Праца, 1870. Том I. 368 с.;

14. Васильчиков А. О самоуправлении. Сравнительный обзор Русских и иностранных земских и общественных учреждений. С.-Петербург: Типограф. Э. Праца, 1870. Том II. 477 с.

15. Илловайский С.И. Учебник финансового права. 4-е изд. Одесса: Типо-Хромо-Лит. А.Ф. Соколовского, 1904. 383 с.

16. Озеров И.Х. Основы финансовой науки. Вып. II. Бюджет. - Формы взимания. Местные финансы. - Государственный кредит. Курс лекций. Москва: Типогр. Т-ва И.Д. Сытина, 1908. 335 с.; II с.

17. Залізняк Л. Стародавня історія України. 2-е вид., доповн. Київ: Темпора, 2019. 274 c.

18. Кольб Г. Фр. История человеческой культуры с очерком форм государственного правления, политики, развития свободы и благосостояния народов; Пер. с 3-го перераб. и знач. доп. нем. изд. под ред. А.А. Рейнгольдта. Кн. вторая. Киев; Харьков: Юж.-рус. кн-во Ф.А. Иогансона, 1896-1899 (Киев). [2]. 472, 588, IV с.

19. Дьяконов М. Очерки общественного и государственного строя Древней Руси. Изд. второе. С.-Петербург: Изд-е Юридического книжного склада «Право», 1908. 509 с.

20. Плохій С. Походження слов'янських націй. Домодерні ідентичності в Україні, Росії та Білорусії. Вид. 3-є, перегл. і випр. Київ: Критика, 2017. 456 с.

21. Кавелин К.Д. О значении слов: варяг, казак, росс и рет // Кавелин К.Д. Собрание сочинений. В 4-х томах. Том первый. Монографии по русской истории. Раасуждения, критические статьи и заметки. С.-Петербург: Типогр. М.М. Стасюлевича, 1897. 1052 с.; IV c.

22. Дымша Л. Государственное право Швеции. Том первый. Часть историческая. С.Петербург: Типогр. П.П. Сойкина, 1901. 404 с.; IV с.

23. Lex Salica // Сборник Законодательных Памятников древнего западноевропейского права, издаваемый под ред. П.Г. Виноградова и М.Ф. Владимирского- 
Буданова. Выпуск первый. Киев: Типогр. Императорского Университета Св. Вдадимира, 1906. C. 194. (326 c.).

24. Черкас Б. Всемирная история. Золотая орда. Покорители Азии. Харьков: Клуб семейного досуга, 2020. 319 с.

25. Історія України. Короткий курс. Під ред. С.М. Бєлоусова, К.Г. Гуслистого, О.П. Оглобліна та ін. Київ: Вид-во Академії наук УРСР, 1941. 411 с.

26. Гуревичь Я.Г., Павлович Б.А. Историческая хрестоматия по русской истории. Часть первая. С.-Петербург: Типогр. Министерства Путей Сообщ., 1877. 512 с.

27. Ярлык, данный Бердебеком Алексею, Митрополиту Киевскому. Около 1357 // Собрание важнейших памятников по истории древнего Русского права. М. Петербург: В Типогр. Губерн. правл., 1859. С. 426-427.

28. Смолій В., Степанков В. Українська національна революція XVII ст. (1648-1676 рр.). Київ: Вид. дім «Києво-Могилянська академія», 2009. 447 с.

29. Павловский И. Фр. Битва под Полтавой 27-го июня 1709 года и ее памятники. Илюстриров. изд. с 129 рисунками и 4 планами. Полтава: Єлектр. Типо-литография И.А. Дохмана, 1908. 243 с.; XXXII с.

30. Конституція Української Гетьманської Держави; передм. С. Головатий; перекл. М. Трофимчук, О. Купрієвич, М. Дольницька. Львів-Київ: Вид-во «Право», 1997. 127 с.

31. Конституційний Договір між Верховною Радою та Президентом України «Про основні засади організації функціонування державної влади і місцевого самоврядування в Україні на період до прийняття нової Конституції України» // Відомості Верховної Ради України. 1995. № 18. Ст. 133.

32. Конституція України, прийнята на п’ятій сесії Верховної Ради України 28 червня 1996 року // Відомості Верховної Ради Украӥни. 1996. № 30. Ст. 141.

33. Про місцеве самоврядування в Україні: Закон України від 21 травня 1997 р. // Відомості Верховної Ради Украӥни. 1997. № 24. Ст. 170.

34. Концепція реформування місцевого самоврядування та територіальної організації влади в Україні: Розпорядження Кабінету Міністрів України від 1 квітня 2014 р. № 333-рп // Офіційний вісник України. 2014. № 30. Ст. 831.

35. Про внесення змін до Конституції України (щодо децентралізації): проект Закону України від 1 липня 2015 р. реєстр. № 2217a / Офіційний веб-сайт Верховної Ради України // URL: http://w1.c1.rada.gov.ua/pls/zweb2/webproc4_1?pf3511=55812

36. Про співробітництво територіальних громад: Закон України від 17 червня 2014 р. // Відомості Верховної Ради Украӥни. 2014. № 34. Ст. 1167.

37. Про добровільне об’єднання територіальних громад: Закон України № 157-VIII від 25 лютого 2015 р. // Відомості Верховної Ради України. 2015. № 13. Ст. 91.

38. Про засади державної регіональної політики : Закону України від 5 лют. 2015 р. Відомості Верховної Ради України. 2015. № 13. Ст. 90.

39. Проект Закону про внесення змін до Конституції України (щодо децентралізації влади) (реєстр. № 2598 від 13.12.2019) // Офіційний веб-портал Верховної Ради України. URL: https://w1.c1.rada.gov.ua/pls/zweb2/webproc4_1?pf3511=67644

\section{References:}

1. Vladimirskiy-Budanov, M.F. (1915). Obzor istorii russkogo prava [Review of the history of Russian law]. (7th ed.). Petrograd; Kiev: Izd-e knizhnogo magaz. N.Ya. Ogloblina [in Russian].

2. Dyakonov, M. (1908). Ocherki obshchestvennogo $i$ gosudarstvennogo stroya Drevney Rusi [Essays on the social and state structure of Ancient Russia]. (2nd ed.). Saint Petersburg: Izd-e Yuridicheskogo knizhnogo sklada «Pravo» [in Russian].

3. Polonska-Vasylenko, N. (1972). Istoriia Ukrainy. I tom (do pol. XVII storichchia) [History of Ukraine. Volume I (until the middle of the XVII century)]. München: Ukrainske vyd-vo [in Ukrainian]. 
4. Polonska-Vasylenko, N. (1976). Istoriia Ukrainy. II tom (vid pol. XVII storichchia do 1923 roku) [History of Ukraine. Volume II (from the middle of the XVII century to 1923)]. München: Ukrainske vyd-vo [in Ukrainian].

5. Bondaruk, T.H. (2009). Mistseve samovriaduvannia ta yoho finansove zabezpechennia v Ukraini [Local self-government and its financial support in Ukraine]. Kyiv [in Ukrainian].

6. Chynchyk, A.A. (2016). Rozvytok doktryny opadatkuvannia v ukrainskii ekonomichnii dumtsi druhoi polovyny XIX - pochatku XX st. [Development of the doctrine of taxation in the Ukrainian economic thought of the second half of XIX - the beginning of XX centuries]. Candidate's thesis. Lviv [in Ukrainian].

7. Batanov, O.V. (2010). Munitsypalna vlada v Ukraini: problemy teorii ta praktyky [Municipal power in Ukraine: problems of theory and practice]. M.O. Baimuratov (Eds.). Kyiv: Yurydychna dumka [in Ukrainian].

8. Fedorenko, V.L. (2016). Poniattia ta konstytutsiini zasady mistsevoho samovriaduvannia [Concepts and constitutional principles of local self-government]. Konstytutsiine pravo Ukrainy Constitutional law of Ukraine. (pp. 573-614). Kyiv: Vyd-vo «Lira» [in Ukrainian].

9. Fedorenko, V.L., Chernezhenko, O.M. (2017). Konstytutsiini modeli mistsevoho samovriaduvannia u derzhavakh-uchasnytsiakh YeS, Shveitsarii ta Ukraini [Constitutional models of local self-government in the member states of the EU, Switzerland and Ukraine]. Kyiv: Vyd-vo «Lira» [in Ukrainian].

10. Hlava IV. osoblyvosti orhanizatsii ta funktsiiuvannia mistsevoho samovriaduvannia $\mathrm{v}$ okremykh evropeiskykh derzhavakh [Chapter IV. Features of the organization and functioning of local self-government in some European countries]. (2020). O.V. Batanov, O.V. Martseliak, A. Berlinhuern (Eds.). Mistseve samovriaduvannia $v$ Ukraini ta zarubizhnykh derzhavakh: porivnialno-pravovi aspekty - Local self-government in Ukraine and foreign countries: comparative legal aspects. (pp. 265-381). Kyiv: Vyd-vo «Osnova» [in Ukrainian].

11. Gagemeyster, Yu.A. (1833). Rozyskaniya o finansakh drevney Rossii [Investigations about the finances of ancient Russia]. Saint Petersburg: Pri Imperat. Akad. Nauk [in Russian].

12. Moroshkin, F. (1837). O vladenii po nachalam Rossiyskogo zakonodatelstva [On the ownership of the principles of Russian legislation]. Moscow: V Universit. Tipografii [in Russian].

13. Vasilchikov, A. (1870). O samoupravlenii. Sravnitelnyy obzor Russkikh i inostrannykh zemskikh $i$ obshchestvennykh uchrezhdeniy [About self-government. Comparative overview of Russian and foreign zemstvo and public institutions]. (Vols. 1). Saint Petersburg: Tipograf. E. Pratsa [in Russian].

14. Vasilchikov, A. (1870). O samoupravlenii. Sravnitelnyy obzor Russkikh i inostrannykh zemskikh $i$ obshchestvennykh uchrezhdeniy [About self-government. Comparative overview of Russian and foreign zemstvo and public institutions]. (Vols. 2). Saint Petersburg: Tipograf. E. Pratsa [in Russian].

15. Illovayskiy, S.I. (1904). Uchebnik finansovogo prava [Financial law textbook]. (4th ed.). Odessa: Tipo-Khromo-Lit. A.F. Sokolovskogo [in Russian].

16. Ozerov, I.Kh. (1908). Osnovy finansovoy nauki. Vyp. II. Byudzhet. - Formy vzimaniya. Mestnye finansy. - Gosudarstvennyy kredit [Fundamentals of Financial Science. Issue II. Budget. Forms of collection. - Local finance. - State loan. Lecture course]. Moscow: Tipogr. T-va I.D. Sytina [in Russian].

17. Zalizniak, L. (2019). Starodavnia istoriia Ukrainy [Ancient history of Ukraine]. (2nd ed.). Kyiv: Tempora [in Ukrainian].

18. Kolb, G. Fr. (1896). Istoriya chelovecheskoy kul'tury s ocherkom form gosudarstvennogo pravleniya, politiki, razvitiya svobody $i$ blagosostoyaniya narodov [History of human culture with an outline of the forms of government, politics, the development of freedom and the well-being of peoples]. A.A. Reyngoldt (Eds.). (Vols. 2). Kiev; Kharkov: Yuzh.-rus. kn-vo F.A. Iogansona [in Russian]. 
19. Dyakonov, M. (1908). Ocherki obshchestvennogo i gosudarstvennogo stroya Drevney Rusi [Essays on the social and state structure of Ancient Russia]. (2nd ed.). Saint Petersburg: Izd-e Yuridicheskogo knizhnogo sklada «Pravo» [in Russian].

20. Plokhii, S. (2017). Pokhodzhennia slovianskykh natsii. Domoderni identychnosti v Ukraini, Rosii ta Bilorusii [The origin of Slavic nations. Pre-modern identities in Ukraine, Russia and Belarus]. (3rd ed., rew.). Kyiv: Krytyka [in Ukrainian].

21. Kavelin, K.D. (1897). O znachenii slov: varyag, kazak, ross i ret [On the meaning of the words: Varangian, Cossack, Ross and Ret]. Sobranie sochineniy. Tom pervyy. Monografii po russkoy istorii. Rassuzhdeniya, kriticheskie stati i zametki - Collected Works. Volume 1. Monographs on Russian history. Judgments, critical articles and notes. (pp. 995-998). Saint Petersburg: Tipogr. M.M. Stasyulevicha [in Russian].

22. Dymsha, L. (1901). Gosudarstvennoe pravo Shvetsii. Tom pervyy. Chast istoricheskaya [State law of Sweden. Volume 1. The historical part]. Saint Petersburg: Tipogr. P.P. Soykina [in Russian].

23. Vinogradov, P.G., Vladimirskiy-Budanov, M.F. (Eds.). (1906). Sbornik Zakonodatelnykh Pamyatnikov drevnego zapadno-evropeyskogo prava. Vypusk pervyy. Lex Salica [Collection of Legislative Monuments of Ancient Western European Law. Issue 1. Lex Salica]. Kiev: Tipogr. Imperatorskogo Universiteta Sv. Vdadimira [in Russian].

24. Cheraks, B. (2020). Vsemirnaya istoriya. Zolotaya orda. Pokoriteli Azii [World history. Golden Horde. Conquerors of Asia]. Kharkov: Klub semeynogo dosuga [in Russian].

25. Bielousov, S.M., K.H. Huslystyi, Ohloblin O.P., et al. (1941). Istoriia Ukrainy [History of Ukraine]. Kyiv: Vyd-vo Akademii nauk URSR [in Ukrainian].

26. Gurevich, Ya.G., Pavlovich, B.A. (1877). Istoricheskaya khrestomatiya po russkoy istorii [Historical anthology on Russian history]. (Vols. 1). Saint Petersburg: Tipogr. Ministerstva Putey Soobshch [in Russian].

27. Yarlyk, dannyy Berdebekom Alekseyu, Mitropolitu Kievskomu. Okolo 1357 [Label given by Berdebek to Alexei, Metropolitan of Kiev. About year 1357]. (1859). Sobranie vazhneyshikh pamyatnikov po istorii drevnego Russkogo prava-Collection of the most important monuments on the history of ancient Russian law. (pp. 426-427). Saint Petersburg: V Tipogr. Gubern. pravl. [in Russian].

28. Smoliy, V., Stepankov, V. (2009). Ukrainska natsionalna revolyutsiya XVII st. (16481676 rr.) [Ukrainian National Revolution of the XVII century. (1648-1676 pp.)]. Kyiv: Vyd. dim «Kyevo-Mohylianska akademiya» [in Ukrainian].

29. Pavlovskiy, I. Fr. (1908). Bitva pod Poltavoy 27-go iyunya 1709 goda i ee pamyatniki [Battle of Poltava on June 27, 1709 and its monuments]. Poltava: Elektr. Tipo-litografiya I.A. Dokhmana [in Russian].

30. Konstytutsiia Ukrainskoi Hetmanskoi Derzhavy [Constitution of the Ukrainian Hetmanate]. (1997). (M. Trofymchuk, O. Kupriievych, M. Dolnytska, Trans). Lviv-Kyiv: Vyd-vo «Pravo» [in Ukrainian].

31. Konstytutsiinyi Dohovir mizh Verkhovnoiu Radoiu ta Prezydentom Ukrainy «Pro osnovni zasady orhanizatsii funktsionuvannia derzhavnoi vlady i mistsevoho samovriaduvannia $\mathrm{v}$ Ukraini na period do pryiniattia novoi Konstytutsii Ukrainy» [Constitutional Treaty between the Verkhovna Rada and the President of Ukraine "On the basic principles of organization of the functioning of state power and local self-government in Ukraine for the period before the adoption of the new Constitution of Ukraine"]. (1995). Vidomosti Verkhovnoi Rady Ukrainy - Bulletin of Verkhovna Rada of Ukraine, 18. Art. 133 [in Ukrainian].

32. Konstytutsiia Ukrainy : vid 28 chervnia 1996 roku [The Constitution of Ukraine]. (1996). Vidomosti Verkhovnoi Rady Ukrainy - Bulletin of Verkhovna Rada of Ukraine, 30. Art. 141 [in Ukrainian]. 
33. Zakon Ukrainy "Pro mistseve samovriaduvannia v Ukraini" : vid 21 travnia 1997 [Law of Ukraine "On local self-government in Ukraine" from May 21, 1997]. (1997). Vidomosti Verkhovnoi Rady Ukrainy - Bulletin of Verkhovna Rada of Ukraine, 24. Art. 170 [in Ukrainian].

34. Rozporiadzhennia Kabinetu Ministriv Ukrainy "Kontseptsiia reformuvannia mistsevoho samovriaduvannia ta terytorialnoi orhanizatsii vlady v Ukraini” : vid 1 kvitnia 2014, № 333-rp [Order of the Cabinet of Ministers of Ukraine "The concept of reforming local self-government and territorial organization of power in Ukraine" from April 1 2014, № 333-rp]. (2014). Ofitsiinyi visnyk Ukrainy - Official Bulletin of Ukraine, 30. Art. 831 [in Ukrainian].

35. Proekt Zakonu Ukrainy "Pro vnesennia zmin do Konstytutsii Ukrainy (shchodo detsentralizatsii)" : vid 1 lypnia 2015, № 2217a [Draft Law of Ukraine "On Amendments to the Constitution of Ukraine (concerning decentralization)” from July 1 2015, № 2217a]. rada.gov.ua. Retrieved from http://w1.c1.rada.gov.ua/pls/zweb2/webproc4_1?pf3511=55812 [in Ukrainian].

36. Zakon Ukrainy "Pro spivrobitnytstvo terytorialnykh hromad" : vid 17 chervnia 2014 [Law of Ukraine "On cooperation of territorial communities" from June 17 2014]. (2014). Vidomosti Verkhovnoi Rady Ukrainy - Bulletin of Verkhovna Rada of Ukraine, 34. Art. 1167 [in Ukrainian].

37. Zakon Ukrainy "Pro dobrovilne obiednannia terytorialnykh hromad" : vid 25 liutoho 2015 № 157-VIII [Law of Ukraine "On voluntary association of territorial communities" from February 25 2015, № 157-VIII]. (2015). Vidomosti Verkhovnoi Rady Ukrainy - Bulletin of Verkhovna Rada of Ukraine, 13. Art. 91 [in Ukrainian].

38. Zakonu Ukrainy "Pro zasady derzhavnoi rehionalnoi polityky" : vid 5 liut. 2015 [Law of Ukraine "On the principles of state regional policy" from 5 February 2015]. (2015). Vidomosti Verkhovnoi Rady Ukrainy - Bulletin of Verkhovna Rada of Ukraine, 13. Art. 90 [in Ukrainian].

39. Proekt Zakonu "Pro vnesennia zmin do Konstytutsii Ukrainy (shchodo detsentralizatsii vlady)" : vid 13.12.2019, № 2598 [Draft Law "On Amendments to the Constitution of Ukraine (concerning decentralization of power)" from December 12 2019, № 2598]. rada.gov.ua. Retrieved from https://w1.c1.rada.gov.ua/pls/zweb2/webproc4_1?pf3511=67644 [in Ukrainian]. 